\begin{tabular}{|l|l|l|}
\hline \multicolumn{2}{|c|}{ PublisherInfo } \\
\hline \hline PublisherName & $:$ & BioMed Central \\
\hline \hline PublisherLocation & $:$ & London \\
\hline \hline PublisherImprintName & $:$ & BioMed Central \\
\hline \hline
\end{tabular}

\title{
Imprinting and methylation
}

\begin{tabular}{|l|l|l||}
\hline \multicolumn{2}{|c|}{ ArticleInfo } \\
\hline \hline ArticleID & $:$ & 4656 \\
\hline \hline ArticleDOI & $:$ & $10.1186 /$ gb-spotlight-20021209-01 \\
\hline \hline ArticleCitationID & $:$ & spotlight-20021209-01 \\
\hline \hline ArticleSequenceNumber & $:$ & 322 \\
\hline \hline ArticleCategory & $:$ & Research news \\
\hline ArticleFirstPage & $:$ & 1 \\
\hline \hline ArticleLastPage & $:$ & 2 \\
\hline \hline & & RegistrationDate : 2002-12-9 \\
\hline ArticleHistory & $:$ & OnlineDate \\
\hline \hline ArticleCopyright & $:$ & BioMed Central Ltd2002-12-9 \\
\hline \hline ArticleGrants & $:$ & \\
\hline \hline ArticleContext & $:$ & 130593311 \\
\hline \hline
\end{tabular}




\section{Jonathan B Weitzman}

Email: jonathanweitzman@hotmail.com

DNA methylation patterns that reflect a chromosome's parental origin are thought to regulate the establishment and maintenance of genomic imprinting. But the mechanisms controlling differential methylation and imprinting have not been elucidated. In an Advanced Online Publication in Nature Genetics Schoenherr et al. describe a role for the zinc-finger protein CTCF in maintaining methylation at the Igf2/H19 imprinted locus (Nature Genetics, 2 December 2002, DOI:10.1038/ng1057). CTCF binds to the unmethylated maternal ICR (imprinting control region) to create a chromatin boundary between the $\operatorname{Igf} 2$ and $H 19$ genes. Schoenherr et al. generated mice with a mutated ICR that bound CTCF very poorly. The mutation resulted in methylation of the maternal ICR allele and re-expression of the maternal $\operatorname{Ig} f 2$ gene and reduced $H 19$ expression levels. Thus, CTCF binding appears to protect from methylation and is essential for the maintenance of differential methylation and imprinting patterns; CTCF is important for establishing the chromatin boundaries that regulate transcriptional territories.

\section{References}

1. Nature Genetics, [http://www.nature.com/ng]

2. H19 and $\operatorname{Ig} f 2$ monoallelic expression is regulated in two distinct ways by a shared cis acting regulatory region upstream of $H 19$. 